\title{
Adaptation test of shade-tolerant soybean to fertilization technology in coconut plantations, Aceh Province
}

\author{
Asis ${ }^{*}$, Fenty Ferayanti, Idawanni, and Lamhot Edy Pakpahan \\ Aceh Assessment Institute of Agricultural Technology, Indonesia
}

\begin{abstract}
Soybean is an important commodity needed by people in Indonesian. Soybean production is currently decreasing every year because off decreasing land area. The available land in Indonesia is mostly used by farmers to cultivate crops that have the potential to meet their economic needs, so that very few farmers use their land for soybean crops. This study aimed to determine the adaptation of shade-tolerant soybean varieties to fertilization technology at various levels of shade coconut plant. The research was conducted at Bandar Baru District, Pidie Jaya Regency, Aceh Province on July to October 2019, with split plot design. The main plot is shade $(\mathrm{N})$, namely $\mathrm{N}_{1}: 0 \%$ shade (without shade); $\mathrm{N}_{2}: 25 \%$ shade and $\mathrm{N} 3$ : $50 \%$ shade, and subplot is the fertilizer package $(\mathrm{P})$ namely $\mathrm{P}_{1}$ : recommendation (NPK $150 \mathrm{~kg} \mathrm{ha}^{-1}$, organic fertilizer $2 \mathrm{t} \mathrm{ha}^{-1}$ ); $\mathrm{P}_{2}$ : specific location (urea $75 \mathrm{~kg} \mathrm{ha}^{-1}, \mathrm{SP}-36100 \mathrm{~kg} \mathrm{ha}^{-1}, \mathrm{KCl} 100 \mathrm{~kg} \mathrm{ha}^{-1}$ ). The results showed that the level of shade had no effect on soybean production, while the fertilization factor showed that the highest production was found in the recommended fertilizer package $1.82 \mathrm{t} \mathrm{ha}^{-1}$, different with the specific location fertilizer package.
\end{abstract}

\section{Introduction}

Soybean (Glycine max (L.) Merr) is one of the important food crops in Indonesia which is widely cultivated in paddy fields and dry land. Soybean products are very much in demand by the public because contain of high protein and fat, as well as raw materials for the animal feed industry and food products. Market demand for soybean commodities were increased with increasing population growth, improving per capita income, increasing public awareness of nutritional needs and the development of various food industries that use soybeans as raw materials [1].

Aceh Province is one of the centers for soybean production in Indonesia. The data on soybean land areas in Aceh in the last 3 years decreased significantly from 37,220 ha in 2015 to 10,025 ha in 2017 which was directly proportional to the decrease in soybean land areas in Pidie Jaya District from 1,293 ha in 2015 to 465 ha in 2017 [2]. The decline in soybean production is influenced by the decreasing land area, the low soybean productivity, the price competition between commodities which caused the low price soybean and the

* Corresponding author: asissp 89@yahoo.co.id 
limited of land ownership [3]. The increased public interest in soybeans and the increased population are not matched by the area of agricultural land that exists or is available in Indonesia. This caused local soybeans become a scarce item. The solution from the government is importing soybeans, because local production is not sufficient for these needs. Some farmers end up using imported soybeans from the USA, Canada, China, Ukraine, and Malaysia in order to get optimal and higher quality results.

Increased the planting area and soybean harvest can be pursued by intercropping with plantation, industrial plants, forest, and food crops. In intercropping pattern, light is often the main factor that can cause various plant responses, that can be additive, synergistic or antagonistic [4]. Sunlight is an environmental variable that affects plant growth [5] and has a significant effect on the photosynthesis process and has an impact on plant survival, growth, and adaptation. Light is the energy source of plant photosynthesis and light intensity has an important influence on plant morphology, physiology and reproduction $[6,7,8]$. The quality and quantity of sunlight can trigger morphological responses [9].

The availability of superior soybean varieties that are adaptive to a shade environment will have an impact on reducing yield losses due to shade stress, increasing productivity and farmers' income in shaded areas. Varieties that are suitable for light-deprived environments are characterized by the physiological adaptability of the varieties concerned in utilizing limited light. Thus, adaptation to the light environment is important for plant survival [10]. The Ministry of Agriculture through the Indonesian Agency for Agricultural Research and Development (IAARD) in December 2014 released two new high yielding varieties of shade tolerant soybeans (up to $50 \%$ ), suitable for development under plantation stands and agroforestry environments with young plants ( $<4$ years), as well as intercropping with other food crops. The two new superior varieties are Dena 1 and Dena 2 [11]. In addition, Anjasmoro is also a soybean variety that is able to adapt and produce high yields in a shade-stressed environment. According to Mawarni [12], the Anjasmoro variety is able to tolerate shading levels of $30 \%$ and $50 \%$. While the results of research by Harahap et al. [13] showed that the productivity of soybean as a cover crop in the immature plantation area (TBM) of oil palm was quite high, namely for the superior variety. This study aims to examine the adaptation of shade-tolerant soybean varieties to fertilization technology at various levels of shading

\section{Materials and methods}

The research was conducted in Paru Keude Village, Bandar Baru District, Pidie Jaya Regency, Aceh Province in July - October 2020. Soil analysis was carried out at the Soil and Plant Laboratory, Institute for Agricultural Technology Assessment, (BPTP) Aceh, Banda Aceh.

The soybean variety used was Dena. The research design used a Randomized Block Design (RBD) with 3 replications and 15 plants were assigned to each treatment as samples. The first factor was the level of shade $(\mathrm{N})$, namely $\mathrm{N}_{1}: 0 \%$ shade (without shade); $\mathrm{N}_{2}$ : Shade $25 \%$ and $\mathrm{N}_{3}$ : Shade $50 \%$. The second factor was the fertilization package $(\mathrm{P})$ which consists of 2 (two) levels : $\mathrm{P}_{1}$ : recommendation (NPK $150 \mathrm{~kg} \mathrm{ha}^{-1}$, organic fertilizer $2 \mathrm{t} \mathrm{ha}^{-1}$ ); P2 : site specific (urea $75 \mathrm{~kg} \mathrm{ha}^{-1}, \mathrm{SP}-36100 \mathrm{~kg} \mathrm{ha}^{-1}, \mathrm{KCl} 100 \mathrm{~kg} \mathrm{ha}^{-1}$ ).

Variables observed were plant height $(\mathrm{cm})$, seed weight $(\mathrm{g})$, weight of 100 seeds $(\mathrm{g})$ and seed yield (ton $\mathrm{ha}^{-1}$ ). Plant height and the number of productive branches were measured at 60 days after the plant (DAP), while seed weight, weight of 100 seeds and productivity were measured at harvesting time.

Soil analysis was carried out using various analytical methods that were appropriate for each parameters, such as soil texture using the hydrometer method [14], $\mathrm{pH}$ with 1: $5 \mathrm{H} 2 \mathrm{O}$ 
extract [15], C-Organic and total nitrogen with Wakley and Black [16,17], phosphorus with $25 \% \mathrm{HCl}$ extract [18] and Olsen [19] and potassium with $25 \% \mathrm{HCl}$ extract [18].

The collected data were subjected to analysis of variance (ANOVA) at a $95 \%$ confidence level, if the $\mathrm{p}$ value is greater than the $\mathrm{p}$ table then followed with the Tukey test at $5 \%$ probability level [20].

\section{Results and discussion}

\subsection{Soil characteristics conditions}

Table 1 shows that soil fertility at the research site was low. Soil C-organic and nutrients content were classified as low, which may not support crop growth optimally. Fertilizers application must be done to produce maximum crop growth and its yield.

Table 1. The results of the soil analysis before research at the research location of the Paru Keude Village, Bandar Baru District, Pidie Jaya, Aceh

\begin{tabular}{|c|c|c|c|}
\hline No & Parameter & Analysis Results & Criteria \\
\hline 1 & Texture & & \multirow{2}{*}{ Sandy clay loam } \\
\hline & -Sand (\%) & 56.90 & \\
\hline & -Silt (\%) & 22.58 & \\
\hline & -Clay (\%) & 20.53 & Acid \\
\hline 2 & $\mathrm{pH}$ & & \\
\hline & $-\mathrm{H} 20$ & 5.85 & Low \\
\hline 3 & Organic Matter & & Low \\
\hline & -C-Organic (\%) & 1.49 & Low \\
\hline & -N total (\%) & 0.16 & \\
\hline & $-\mathrm{C} / \mathrm{N}$ & 9.23 & Low \\
\hline 4 & Extract $\mathrm{HCl} 25 \%$ & & Low \\
\hline & $-\mathrm{P}_{2} \mathrm{O}_{5}\left(\mathrm{mg} 100 \mathrm{~g}^{1}\right)$ & 16.56 & \\
\hline & $-\mathrm{K}_{2} \mathrm{O}\left(\mathrm{mg}^{100 \mathrm{~g}^{-1}}\right)$ & 19.28 & \\
\hline
\end{tabular}

Note: Results of the analysis of the Soil and Plant Laboratory, Aceh Institute of Agricultural Technology

\subsection{Plant growth and production}

Analyses of variance of the parameters observed are shown in Table 2. All the parameters were significantly influenced by shading levels, however only plant height which was affected by fertilizer application. Interaction effects of shading level and fertilizers application was only found on the plant height. 
Table 2. Results of analysis of variance ANOVA on various observation variables of adaptation test of shade-resistant soybean varieties to fertilization technology at various levels of shade

\begin{tabular}{|c|c|c|c|}
\hline \multirow{2}{*}{ Variables } & \multicolumn{2}{|c|}{ Independent } & \multirow{2}{*}{ Interaction } \\
\hline & Shading & Fertilizer & \\
\hline Plant height $60 \mathrm{DAP}$ & $* *$ & ** & ** \\
\hline Seed weight & $* *$ & ns & ns \\
\hline Weight 100 seeds & ** & $\mathrm{ns}$ & ns \\
\hline Yield & $* *$ & $\mathrm{~ns}$ & ns \\
\hline
\end{tabular}

Note: $\mathrm{ns}=$ not significant effect, $*=$ significan effect $(0.05), * *=$ very significant effect $(0.01)$

\subsection{Plant height}

Vegetative growth is very important for development in the generative phase. Optimal vegetative growth will encourage optimal generative growth so that high yields will be obtained. Observation of plant height is one of the main parameters to determine the level of adaptation of a variety in an agroecosystem.

Table 3. The results of the $95 \%$ Tukey analysis of adaptation test of shade-resistant soybean with fertilization technology on plant height at ages 60 DAP

\begin{tabular}{|c|c|c|c|c|c|c|}
\hline \multirow{2}{*}{ Variables } & \multicolumn{6}{|c|}{ Treatment } \\
\cline { 2 - 7 } & $\mathbf{N}_{\mathbf{1}} \mathbf{P}_{\mathbf{1}}$ & $\mathbf{N}_{\mathbf{1}} \mathbf{P}_{\mathbf{2}}$ & $\mathbf{N}_{\mathbf{2}} \mathbf{P}_{\mathbf{1}}$ & $\mathbf{N}_{\mathbf{2}} \mathbf{P}_{\mathbf{2}}$ & $\mathbf{N}_{\mathbf{3}} \mathbf{P}_{\mathbf{1}}$ & $\mathbf{N}_{\mathbf{3}} \mathbf{P}_{\mathbf{2}}$ \\
\hline Plant height 60 DAP $(\mathrm{cm})$ & $87,67 \mathrm{c}$ & $89,81 \mathrm{bc}$ & $91,20 \mathrm{~b}$ & $94,00 \mathrm{a}$ & $93,40 \mathrm{a}$ & $88,67 \mathrm{c}$ \\
\hline
\end{tabular}

Note: Numbers accompanied by different letters in each column and row show significantly different based on the $95 \%$ Tukey test

Table 3 shows plant height of soybean under different shading levels and fertilizer application. The highest plant was reached on $25 \%$ shading level and site specific fertilizer package. As the shading level increased to $50 \%$, the plant height tended to decreased. This happens because plant growth is strongly influenced by environmental conditions around the growing plant. Plants can experience morphological changes if environmental conditions experience stress intensity. Growth is closely related to the potential interaction of soybean plants with the environment [17].

The higher the intensity of the shade, the lower the level of sunlight received by soybean plants. The low light intensity during plant development will cause etiolation symptoms caused by the activity of the auxin hormone. The part of the plant crown that is exposed to light will grow slowly because the action of auxin is inhibited by light, while the part of the crown of the plant that is not exposed to light grows very fast because the action of auxin is not inhibited. This condition makes the crown (apical) of the plant experience the most active growth so that the plant grows looking for light to carry out more optimal photosynthesis. Plant height in shade treatment was higher than without shade. Shade reduces the intensity of light received by plants, resulting in etiolation [21]. Some research results also state that shade causes an increase in plant height and reduces the size of soybean stem diameter [22,23]. According to Sundari et al. [24] the difference in plant height is caused by differences in the level of shade, the higher the level of shade, the lower the level of light acceptance by soybean plants so as to stimulate apical dominance which causes internode elongation and reduces stem diameter. 


\subsection{Seed weight, weight of 100 seeds and yield $\left(\mathrm{t} \mathrm{ha}^{-1}\right)$}

The results of the analysis of seed weight variance showed that the shade level treatment for the Dena variety had a significant effect on the seed weight (Table 4). The highest seed weight was found at the $25 \%$ shade level $\left(\mathrm{N}_{2}\right) 21.06 \mathrm{~g}$, while the lowest seed weight was found at the $50 \%$ shade level $\left(\mathrm{N}_{3}\right) 18.69 \mathrm{~g}$. While the fertilization package treatment had a significant effect on seed weight where the highest seed weight was found in the recommended fertilization package treatment $20.76 \mathrm{~g}$. The decrease in seed weight due to shade is caused by the inhibition of plant metabolic processes due to low light intensity. This resulted in a decrease in the supply of photosynthate to the seeds. The decrease in seed weight due to shade is caused by shaded conditions where plants experience a limited amount of solar energy absorbed for the photosynthesis process, resulting in reduced seed weight and plant stover [23].

Table 4. The results of the $95 \%$ Tukey analysis of adaptation test of shade-resistant soybean with fertilization technology on seed weight, weight of 100 seeds and yield

\begin{tabular}{|c|l|l|l|l|l|}
\hline \multirow{2}{*}{ Variables } & \multicolumn{5}{|c|}{ Individually } \\
\cline { 2 - 6 } & \multicolumn{4}{|c|}{ Shades } & \multicolumn{1}{c|}{ Fertilizer Package } \\
\cline { 2 - 6 } & \multicolumn{1}{|c}{ N1 } & \multicolumn{1}{|c|}{ N2 } & \multicolumn{1}{|c|}{ N3 } & P1 & P2 \\
\hline Seed Weight $(\mathrm{g})$ & $19.83 \mathrm{~b}$ & $21.06 \mathrm{a}$ & $18.69 \mathrm{~b}$ & $20.76 \mathrm{a}$ & $18.96 \mathrm{~b}$ \\
\hline Weight of $100 \mathrm{seeds}(\mathrm{g})$ & 15.45 & 16.03 & 15.29 & $16.39 \mathrm{a}$ & $14.79 \mathrm{~b}$ \\
\hline Yield $\left(\mathrm{t} \mathrm{ha}^{-1}\right)$ & 1.62 & 1.69 & 1.75 & $1.82 \mathrm{a}$ & $1.56 \mathrm{~b}$ \\
\hline
\end{tabular}

Note: Numbers accompanied by different letters in each column and row show significantly different based on the $95 \%$ Tukey test

The results of the analysis of weight variance of 100 seeds showed that the shade level treatment had no significant effect on the weight of 100 seeds of Dena variety soybean (Table 4). Meanwhile, the fertilization package treatment significantly affected the weight of 100 seeds where the recommended fertilization package had the highest weight of 100 seeds $16.39 \mathrm{~g}$. Salimi et al. [25] reported that the character of seed weight per plant and weight of 100 seeds gave a greater contribution than other characters to the total diversity of soybeans. Exposure that is too short or too long will have an impact on decreasing production [26]. The results of the analysis of variance on yield showed that the treatment of various levels of shade on the Dena variety did not affected the yield $\left(\mathrm{t} \mathrm{ha}^{-1}\right)$, while the recommended fertilization package had a significant effect on the yield, where the highest yield was 1.82 tons.

\section{Conclusions}

The results showed that the level of shade had no effect on production, while the fertilization factor showed that the highest production was found in the recommended fertilizer package $1.82 \mathrm{t}$ ha-1.

\section{References}

1. N. Soverda, J. Univ. Jambi. 1, 1-13, (2012).

2. Indonesian Bureau of Statistics (IBS), Aceh dalam angka Tahun 2018 (Banda Aceh, 2018) 
3. Directorate General of Food Crops, Laporan Tahunan Direktorat Jenderal Tanaman Pangan (Kementerian Pertanian, Jakarta, 2013)

4. J. Zhang, D.L. Smith, W. Liu, X. Chen,W. Yang, The African J. Biotech. 10, 1439214398 (2011)

5. A. Janska, P. Marsik, S. Zelenkova, J. Ovesna, Annual Review Plant. Biol. 12, 395405 (2009)

6. N. Wang, Q. Huang, J. Sun, S. Yan, C. Ding, X. Mei, D. Li, X. Zeng, X. Su, Y. Shen, Forest Ecol. Manag. 331, 40-49 (2014)

7. C. Kosma, Triantafyllidis, V. Papasavvas, A. Salahas, G. Patakas, J. Food Agric. 25, 974-979 (2013)

8. R. P. Mauro, O. Sortino, M. Dipasquale, J. Agric. Sci. 152, 917-931 (2014)

9. L.V. Kurepin, J.R.N. Emery, R.P. Pharis , D.M. Reid, J. Exp. Bot. 58, 2145-2157 (2007)

10. T. Araki, T.T. Oo, F. Kubota, Environ. Control Biol. 52, 4, 227-231 (2014)

11. Balai Penelitian Tanaman Aneka Kacang Dan Umbi, Varietas Baru Unggul Toleran Naungan (Balitkabi, Malang, 2015)

12. L. Mawarni, J. Ilmu Pertan. 5, 54-59 (2015)

13. I.Y. Harahap, B. Bangun, T.C. Hidayat, Bul. Kelapa Sawit. 1 (2008)

14. C.J. Bouyoucos, Agronomy J. 54, 464-465 (1962)

15. ISRIC, Prosedures for soil analysis, In Technical Paper, International Soil Reference and Information Centre (Wageningen, The Netherlands. $4^{\text {th }}$ ed. P.100, 1993)

16. C.A. Black, Methods of soil analysis, Part 2, Agronomy 9. P, 771-1 (Chemical and Mikrobiological properties, USA, 1965)

17. M. Sudjadi, I.M. Widjik, M. Soleh, Penuntun analisis tanah (Bogor, Indonesia, 1971)

18. F.S. Watanabe, R. Olsen, Soil Sci. Am. Proc. 29, 677-678 (1965)

19. R.G.D. Steel, J.H. Torrie, Principle and procedures of statistics (With special reference to the biological sciences.) (McGraw-Hill Book Company, London, 1960)

20. T. Sundari, N. Nugrahaeni, G.W.A. Susanto, J. Agron. Indonesia. 44, 16-25 (2016)

21. C.Y. Li, Z.D. Sun, H.Z. Chen, S.Z. Yang, J. Agric. Sci. 19, 265-269 (2006)

22. J. Bakhshy, K. Ghassemi-Golezani, S. Zehtab-Salmasi, M. Moghaddam, Tech J. Engin. App Sci. 3, 39-43 (2013)

23. Chairudin, Efendi, Sabaruddin, J. Floratek. 10, 26-35 (2015)

24. Sundari, Titik, Purwantoro, Penelit. Pertan. Tanaman Pangan. 33, 1, (2014).

25. S. Salimi, H.S. Samiezade, G.M. Abadi, S. Moradi, World Appl. Sci. J. 16, 474- 478 (2012)

26. Ariffin, Agrivita. 30, 61-66 (2008) 